\title{
Effect of an Encapsulated Anti-Elastase Compound on Experimental Gingival Inflammation in the Rat
}

\author{
Fadila Guessous ${ }^{1,2}$, Ahmed El Abbouyi ${ }^{2}$, Jean-Paul Giroud ${ }^{1}$, Jean Meyer ${ }^{3}$ and Monique Roch-Arveiller ${ }^{1}$ \\ 1 Département de Pharmacologie, CNRS URA 1534, Hôpital Cochin, Paris, France \\ 2 Département de Biochimie, Faculté des Sciences, El Jadida, Maroc \\ ${ }^{3}$ Département de Parodontologie, Faculté de Chirurgie Dentaire, Montrouge, France
}

Summary: An animal (rat) model of gingival injury ("impaction") induced a gingival inflammatory reaction, which was characterized by a breakdown of gingival collagen and the elastic network, as well as a significant increase of gingival elastase. The present study was conducted to investigate whether ceramides, sphingolipids composed of sphingosine $\mathrm{N}$-acyl-linked to fatty acids, a chemical structure with antielastase properties, could counteract the development of such an inflammatory process.

The ceramides used in these experimental series were extracted from wheat and characterized. The main fatty acids were $16: 0,18: 1,18: 2$, and the sphingoid moiety was phytosphingosine. Inhibition of elastase by ceramides was demonstrated in vitro and the concentration necessary to inhibit $50 \%$ of elastase activity was $41 \mathrm{mg} / \mathrm{l}$ using the synthetic substrate methoxysuccinyl-alanine-alanine-proline-valine-p-nitroanilide (MeOSuc-AlaAlaProValpNA). However, this anti-elastase activity was not observed in vivo in our animal model of gingival inflammation.

A glycosaminoglycan (Heparin ${ }^{\circledR}$ ), recognized as a potent inhibitor of elastase, was entrapped in ceramides. A local treatment of impacted gingivae by encapsulated heparin led to a dose-related decrease of the elastase level in gingival extracts. Encapsulation in ceramides potentiated the effect exerted by heparin alone. This inhibitory effect of encapsulated heparin on elastase suggested a vector effect of these amphipathic molecules.

\section{Introduction}

Periodontitis is an infectious periodontal disease with an irregular evolution, characterized by gingival inflammation mainly due to bacteria $(1,2)$. Clinical criteria such as radiographs, pocket depth and bleeding on probing are needed for periodontitis diagnosis. Some markers such as enzymes ${ }^{1}$ ) and inflammatory mediators have also been investigated in gingival fluid in order to include biochemical criteria in the diagnosis. These markers include collagenase $(3,4)$, gelatinase $(5,6)$, lactoferrin (7), $\gamma$-glucuronidase (8), aspartate aminotransferase (9), and elastase (10-14).

The gingival proteinases, collagenase and elastase, have received a great deal of attention during the past few years, since tissue destruction by these enzymes plays a major role in the pathogenesis of periodontitis. In healthy tissues, matrix macromolecules are protected against elastase destruction by natural inhibitors such as $\alpha_{1}$-antiprotease, $\alpha_{2}$-macroglobulin and $\alpha_{1}$-antichymotrypsin (15) which are endogenous regulators of this enzyme

\footnotetext{
1) Enzymes:

Neutrophil elastase EC 3.4.21.37;

Neutrophil collagenase EC 3.4.24.34
}

activity. However, during inflammatory episodes, polymorphonuclear leukocytes release numerous enzymes and oxidants which can inactivate these natural inhibitors. Therefore, exogenous natural or synthetic antielastase compounds might be efficient in preventing tissue damage.

Elastase is a serine proteinase capable of digesting various components of the extracellular matrix (16), which plays a central role in connective tissue destruction associated with the inflammatory process. It has been demonstrated that several lipidic substances inhibit the serine proteases, pancreatic elastase and plasmin $(17,18)$. The three-dimensional structure of leukocyte elastase shows an unusual hydrophobic pocket near its active site that can accommodate cis-unsaturated long chain fatty acids and their derivatives $(19,20)$. By binding to this pocket, glycosaminoglycans such as heparin and heparan sulphate may act as strong inhibitors of leukocyte elastase (21).

Ceramides are sphingolipids composed of sphingosine $\mathrm{N}$-acyl linked to fatty acids, conferring an hydrophobic character on the molecule. Owing to their hydrophobic structure, it has been suggested that ceramides extracted from wheat, composed of dehydrophytosphingosine, 
phytosphingosine, dihydrophytosphingosine and polyunsaturated fatty acids, may inhibit leukocyte elastase in vitro and thus prevent matrix alterations (22).

In previous experiments in the rat (23), we demonstrated that elastic components decreased significantly only when bacteria were added to the mechanical injury. A significant enhancement of gingival elastase level appeared in parallel to the number of invading inflammatory cells, mostly represented by polymorphonuclear leukocytes, which represent the major source of released elastase.

The aim of this work was to investigate whether ceramides, containing or not containing an antielastase compound such as heparin, could counteract the evolution of a gingival-induced inflammation which shows many features of periodontal diseases (23).

\section{Materials and Methods}

Reagents

Purified human leukocyte elastase was from Elastin Products Company (St. Louis, MO, USA).

Methoxysuccinyl-(Ala $)_{2}$-Pro-Val-pNA was from Sigma (St. Louis, MO).

Heparin was from Léo Lab. (Paris, Fance).

Ceramides were extracted and purified by INOCOSM (ChatenayMalabry, France).

\section{Extraction of ceramides from wheat}

Wheat grains (Joss variety) were ground to powder and extracted several times with combinations of solvents containing various proportions of methanol, chloroform and acetone (European patent No 91-06-336 PCT/FR92/00182). Triacylglycerols were removed by treating isolated ceramides with acetone. Ceramides were then recrystallized, treated with active charcoal, dried, crushed and micronized.

\section{Characterization of wheat ceramides}

Wheat ceramides were characterized by thin layer chromatography, gas chromatography-mass spectrometry and infrared spectroscopy.

Thin-layer chromatography was performed on Silica gel 60 plates (Merck, Darmstadt, Germany) using chloroform/hexane/methanol/ acetic acid/water $(24+14+8+6+0.6$ by vol. $)$ as the solvent. The detection reagent was $10 \mathrm{~g}$ of copper II sulphate in $100 \mathrm{ml}$ of $80 \mathrm{~g} / 1$ phosphoric acid solution. Individual ceramides were quantified by densitometry coupled with a Donatec $385 / 16$ computer.

For gas chromatography-mass spectrometry analysis, an HP 5989 A spectrometer was used with an electron energy of $22 \mathrm{eV}$. Compounds were run on a $\mathrm{HP} 1$ column conditioned at $280^{\circ} \mathrm{C}$ with a helium (carrier gas) pressure of $15 \mathrm{psi}$ on the column head. The standard Grob-split-splitless injector was used in the splitless mode. Esterified fatty acids from hydrolysed ceramides was performed with a NICOLET SX 730 infrared spectrometer equipped with Fourier transformation and a silicon carbide infrared source. Non-hydrolysed ceramides were dissolved in dimethylsulphoxide for infrared spectroscopy.

Determination of solubilities of ceramides in dimethylsulphoxide

Stock solutions of ceramides were prepared in dimethylsulphoxide. Fifty microlitres were withdrawn and added to $100 \mathrm{mmol} / \mathrm{l}$ Tris/
$\mathrm{HCl} \mathrm{pH} 8.0$ containing $0.1 \mathrm{ml} / 1$ Triton $\mathrm{X}-100$ and $0.2 \mathrm{~g} / 1$ sodium azide $\left(\mathrm{NaN}_{3}\right)$. The turbidity of the solution was evaluated by laser nephelometry (Behring laser nephelometer, Behring Institute, France) and values were corrected for blanks consisting of buffer containing the same amount of dimethylsulphoxide. Solubility limits corresponded to changes in the slope of the nephelometric curve (24).

\section{Enzyme kinetics using MeOSucAlaAlaProValpNA}

Stock solutions of methoxysuccinyl-alanine-alanine-proline-valine$p$-nitroanilide (MeOSucAlaAlaProValpNA) were prepared in $\mathrm{N}$ methylpyrrolidone and stored in the dark at $4{ }^{\circ} \mathrm{C}$. Human neutrophil elastase activity was determined at $37^{\circ} \mathrm{C}$ in thermostated polystyrene cuvettes with $100 \mathrm{mmol} / \mathrm{Tris} / \mathrm{HCl} \mathrm{pH} 8.0$ containing 0.1 $\mathrm{ml} / 1$ Triton $\mathrm{X}-100$ and $0.2 \mathrm{~g} / 1$ sodium azide $\left(\mathrm{NaN}_{3}\right)$. Human neutrophil elastase $(16.1 \mathrm{nmol} / \mathrm{l})$ was preincubated for $5 \mathrm{~min}$ with 5 to $62.5 \mathrm{mg} / \mathrm{l}$ of ceramide. Synthetic substrate $(0.025$ to $0.2 \mathrm{mmol} / \mathrm{l})$ was then added. The release of $p$-nitroaniline was recorded at 410 $\mathrm{nm}$ with a spectrophotometer (Philips PU $8740 \mathrm{UV} / \mathrm{Vis}$ ). The inhibitory capacity of ceramide was expressed as percentage of inhibition: $\% \mathrm{I}=(1-\mathrm{Vi} / \mathrm{Vo}) \times 100$ where $\mathrm{Vi}$ is the velocity in the presence of the inhibitor and Vo in the absence of the inhibitor, containing the same amount of dimethylsulphoxide.

\section{Experimental gingival inflammation "Impaction"}

Male Sprague-Dawley Rats (Depré, Saint-Doulchard, France) weighing $180-200 \mathrm{~g}$ were housed at $21-24^{\circ} \mathrm{C}$, given chows and distilled water ad libitum. Gingival inflammation was induced using the bacterial strain Treponema denticola (IP 6444) as described before (23).

\section{Collection of samples}

Animals were euthanized with ether, 10 days after impaction. Gingivae were dissected under a binocular microscope, weighed and placed in sterile plastic microcentrifuge tubes (Eppendorf $0.7 \mathrm{ml}$ ) containing $10 \mu \mathrm{l}$ of phosphate-buffered saline and $0.1 \mathrm{~g} / 1$ Brij 35, $\mathrm{pH}=8$, in order to minimize evaporation and protease inhibition (25). These samples were used for elastase assay.

\section{Elastase assays}

Gingivae, frozen $\left(-20^{\circ} \mathrm{C}\right)$ after collection, were cut with a cryostat into $10 \mu \mathrm{m}$ slices and suspended in Tris buffer $(100 \mathrm{mmol} / 1$ Tris/ $\mathrm{HCl}, \mathrm{NaCl} 1 \mathrm{~mol} / \mathrm{l}$, Brij $350.1 \mathrm{~g} / \mathrm{l}, \mathrm{NaN}_{3} 0.2 \mathrm{~g} / \mathrm{l}, \mathrm{pH}=8$ ). After shaking for $24 \mathrm{~h}$ at $4{ }^{\circ} \mathrm{C}$, they were centrifuged, and the supernatant was collected for elastase measurement. Elastase activity was determined using MeOSucAlaAlaProValpNA as substrate.

Briefly, a $125 \mathrm{mmol} / \mathrm{l}$ stock solution of the substrate was prepared in $\mathrm{N}$-methylpyrrolidone. Next, $20 \mu \mathrm{l}$ of this solution were added to 960 $\mu \mathrm{l}$ of buffered solution consisting of $100 \mathrm{mmol} / \mathrm{Tris} \mathrm{HCl}, 0.1 \mathrm{~g} / \mathrm{l} \mathrm{Brij}$ $35,0.2 \mathrm{~g} / \mathrm{l} \mathrm{NaN}_{3}$, and $20 \mu \mathrm{l}$ of sample. The mixture was incubated for $24 \mathrm{~h}$ at $37^{\circ} \mathrm{C}$ and absorbance was recorded at $410 \mathrm{~nm}$ in a spectrophotometer (Beckman). Standard curves of substrate hydrolysis were obtained using titrated purified human leukocyte elastase (Elastin Products Company, St. Louis, MO, USA). Results were expressed as ng of active elastase per $\mathrm{mg}$ of proteins of the sample.

\section{Pharmacological assay}

Rat gingivae impacted with Treponema denticola were locally treated with ceramides (prepared with gum arabic and stored in the dark in small sterile flasks at $4{ }^{\circ} \mathrm{C}$ ) with or without heparin (25 $\times 10^{3}$ and $\left.50 \times 10^{3} \mathrm{IU} / \mathrm{l}\right)$ every day at the same hour until animal sacrifice. Control animals were not infected.

The level of elastase measured in each biopsy was related to the amount of protein measured by Lowry's technique.

\section{Statistical analysis}

One way analysis of variance (Anova from the computer program Statview II) provided an initial estimate of whether the groups were 
significantly different. Unpaired Student's $t$ test was calculated in each group between treated and non-treated rats. Results were given as means \pm S.E.M. Differences with $p<0.05$ were considered as significant.

\section{Results}

\section{Characterization of wheat ceramides}

Table 1 and figure 1 show the composition and the structure of wheat ceramides. The major fatty acids are palmitic acid (16:0), oleic acid $(18: 1)$ and linoleic acid (18:2), representing 19,12 and $53 \%$ of total fatty acids, respectively. However the exact composition of the mono-, di-, tri- and polyglycosyl ceramides were not determined. The absence of any absorption when infrared spectroscopy was used suggested that the sphingosine moiety is a phytosphingosine.

\section{Determination of solubility}

Figure 2 shows the solubility limit of ceramides which corresponds to a change in the slope of the nephelometric curve. This value was equal to $80 \mathrm{mg} / \mathrm{l}$. Therefore, subsequent enzymatic and pharmacological studies were performed with concentrations below this value.

\section{Inhibition of elastase by ceramide}

For testing the inhibition of elastase by wheat ceramides in vitro, we used the specific synthetic substrate $\mathrm{MeO}$ SucAlaAlaProVal $p$ NA. Figure 3 represents the percentage of inhibition of elastase by ceramide at concentrations from 5 to $62.5 \mathrm{mg} / \mathrm{l}$. Inhibition of leukocyte elastase increased with the increase of ceramide concentration used (below solubility limits). Previous studies

Tab. 1 Fatty acid composition of wheat ceramides.

\begin{tabular}{lll}
\hline Fatty acids & Non-hydroxylated & Hydroxylated \\
\hline $16: 0$ & 19.04 & - \\
$18: 0$ & 5.10 & - \\
$18: 1$ & 12.30 & - \\
$18: 2$ & 53.22 & - \\
$20: 0$ & 0.61 & 1.65 \\
$20: 1$ & 1.05 & - \\
$22: 0$ & 2.56 & 1.88 \\
$22: 1$ & - & 0.47 \\
$24: 0$ & 0.65 & - \\
$26: 0$ & 0.85 & - \\
$28: 0$ & 0.67 & - \\
\hline
\end{tabular}

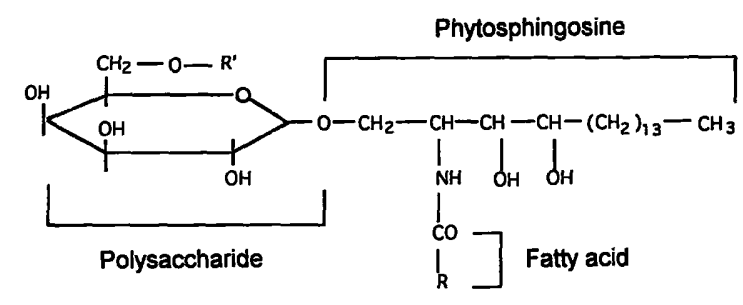

Fig. 1 Fatty acid composition of wheat ceramides.

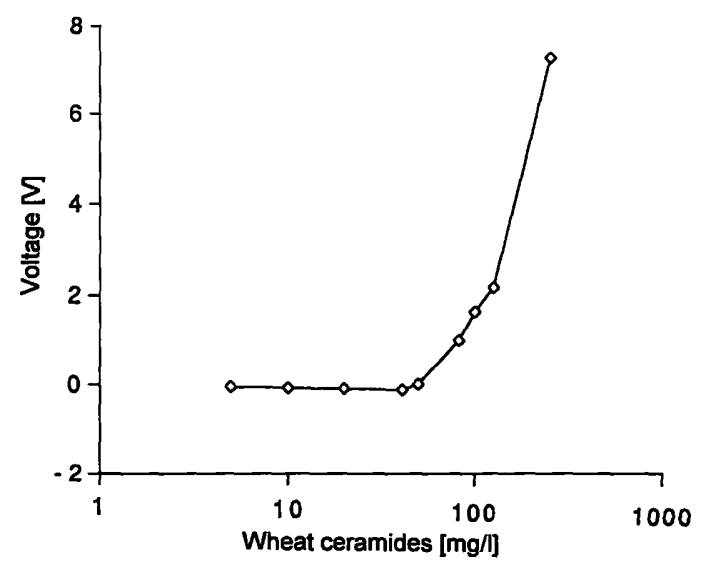

Fig. 2 Limit of solubility of wheat ceramides.

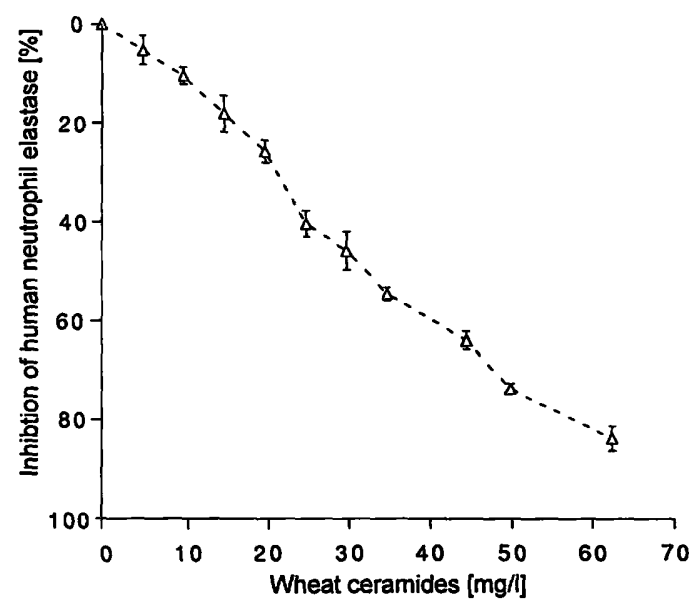

Fig. 3 Inhibition of human neutrophil elastase by wheat ceramides (\%).

(unpublished data analysed by Baici's equation (26)) showed that this inhibition, hyperbolic and non-competitive for concentrations below $20 \mathrm{mg} / 1$, becomes mixed and linear at higher concentrations.

\section{Pharmacological assay}

Figure 4 shows that the elastase level was very low in controls. This value was significantly increased when gingivae were impacted with Treponema denticola. Ceramides did not prevent this increase. However, this value decreased significantly in gingivae treated locally with heparin $(50 \mathrm{U})$, and this effect was dose-related (data not shown). This effect was potentiated when heparin was encapsulated in ceramides. Only these data have been reported in figure 4 .

\section{Discussion}

In the present work we demonstrated that our model of gingival inflammation can be used to test the capacities of some anti-elastase substances to protect and/or to prevent destruction of extracellular matrix macromolecules. 


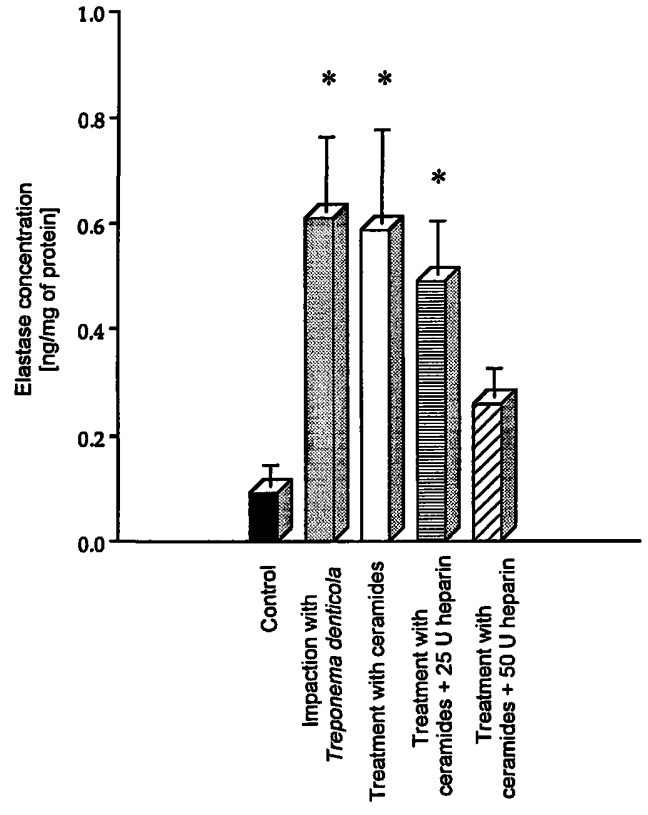

Fig. 4 Amounts of neutrophil elastase (ng/mg of proteins \pm SEM) in control gingivae, gingivae impacted with Treponema denticola, gingivae impacted with Treponema denticola and treated with ceramides alone or ceramides associated to heparin $25 \mathrm{U}$ and heparin $50 \mathrm{U}$.

$* \mathrm{p}<0.05$ by comparison to control value

number of animals in each group: 6 to 8 .

There are a number of biological markers of periodontal diseases but elastase derived from polymorphonuclear leukocytes is certainly the most important one. The increase of elastase in gingival extracts after "impaction" with bacteria parallels the migration of inflammatory cells (essentially polymorphonuclear leukocytes) towards the focus of inflammation. These cells then release their lysosomal content, including enzymes and mediators. This degranulation process is followed by degradation and disorganization of the gingival elastic network, especially when gingival infection occurs (23). These results corroborated the findings of BonnaureMallet (27) who showed that pathogens play a pivotal role in the establishment of the disease, and who observed a modification of gingival elastic fibres in patients with severe periodontitis, similar to that observed in impacted animals.

Elastase, derived from polymorphonuclear leukocytes, has a high affinity for lipophilic substances, and an even higher affinity for long-chain unsaturated fatty acids and their derivatives, owing to the presence of an hydrophobic pocket near its active site $(19,20)$. Oleic acid is the most potent inhibitor, and it is capable of combining with either substrate or enzyme (28).

Recent data indicated that the extended substrate binding domain of leukocyte elastase can accommodate a large variety of hydrophobic lipids (not only fatty acids) like fatty acyl-saccharins (29), polycyclic molecules such as steroidal anti-inflammatory drugs (30) and some cephalosporin derivatives (31). It was speculated that the Nacyl linkage of fatty acid to phytosphingosine confers high hydrophobicity on wheat ceramides, allowing their interaction with the active site of elastase. Besides their physiological properties such as skin hydration, regulation of cellular growth and differentiation (32), we demonstrated in this work that ceramides extracted from wheat possess anti-elastase activity in vitro. The same results were obtained when the inhibitory properties of ceramide were tested on natural substrate (radiolabelled elastin) or on healthy human skin (22).

Heparin and its sulphated derivative, heparan sulphate, are strong inhibitors of leukocyte elastase (21). The same inhibitory activity was demonstrated against both elastase and cathepsin $\mathrm{G}$ by $\mathrm{N}$-oleoylheparin (20). It has been demonstrated that heparin fragments such as oleoyl peptide conjugates are efficient in preventing emphysema induced in rodents by intra-tracheal elastase instillation $(33,34)$.

After "impaction" of gingivae, we observed a significant enhancement of the elastase content of gingival extracts, which parallelled the presence of migratory invading cells (especially polymorphonuclear leukocytes) attracted by various chemoattractants, as previously observed in skin diseases (35). Unlike bifunctional inhibitors, such as oleic acid, the ceramides were unable to bind elastin (22). Protection of the substrate by ceramides therefore consists of inhibition of the enzyme only.

Our experiments showed that local treatment by heparin of impacted gingivae led to a dose related decrease of the elastase level in gingival extract. This inhibiting effect of heparin on elastase was potentiated by association with ceramides, suggesting the possible existence of a vector effect of these amphipathic molecules. A vector effect has already been demonstrated after oral administration of encapsulated superoxide dismutase in liposomes containing ceramides $(36,37)$.

This preliminary pharmacological assay performed to validate our animal gingival lesion model with a very potent anti-elastase substance opens a large field of investigations on natural or synthetic anti-elastase molecules. Such substances might prevent the destruction of gingival macromolecules which occurs during inflammatory injury and might be useful in therapeutic treatment of periodontal diseases.

\section{Acknowledgements}

The authors gratefully thank Mr. Olivier Muntaner for his excellent technical assistance. 


\section{References}

1. Goodson JM, Tanner AC, Haffajee AD, Sornberger GC, Socransky SS. Patterns of progression and regression of advanced destructive periodontal disease. J Clin Periodontol $1982 ; 9: 472-81$.

2. Socransky S, Haffajee A, Goodson JM, Linhe J. New concepts of destructive periodontal disease. J Clin Res 1984; 11:21-32.

3. Villela B, Cogen RB, Bartolucci AA, Birkedal-Hansen H. Collagenolytic activity in crevicular fluid from patients with chronic adult periodontitis and gingivitis, and from healthy control subjects. J Periodontol Res 1987; 22:381-9.

4. Hakkarainen $\mathrm{K}$, Uitto VJ, Ainamo J. Collagenase activity and protein content of sulcular fluid after scaling and occlusal adjustment of teeth with deep periodontal pockets. J Periodontol Res 1988; 23:204-10.

5. Teng YT, Sodek J, McCulloch CAG. Gingival crevicular fluid gelatinase and its relationship to periodontal disease in human subjects. J Periodontol Res 1992; 2:544-52.

6. Mäkelä M, Salo T, Uitto VJ, Larjava H. Matrix metalloproteinases (MMP-2 and MMP-9) of the oral cavity: cellular origin and relationship to periodontal status. J Dent Res 1994; 73:709-21.

7. Adonogianaki E, Moughal NA, Kinane DF. Lactoferrin as a marker of polymorphonuclear leukocytes in periodontal disease. J Clin Periodontol 1993; 20:26-31.

8. Lamster IB, Oshrain RL, Celenti RS, Fine JB, Grbic T. Indicators of the acute inflammatory and humoral immune responses in gingival crevicular fluid: relationship to active periodontal disease. J Periodontal Res 1991; 26:261-3.

9. Persson GR, Page RC. Effect of sampling time and reception on gingival crevicular fluid and aspartate amino-transferase activity. J Periodontol Res 1990; 25:63-7.

10. Cox SW, Cho K, Eley BM, Smith RE. A simple, combined fluorogenic and chromogenic method for the assay of proteases in gingival crevicular fluid. J Periodontol Res 1990; 25:164-71.

11. Zafiropoulos GGK, Flores-de-Jacoby L, Todt G, Kolb G, Havemann K, Tatakis DN. Gingival fluid elastase-inhibitor complex: correlation with clinical indices and subgingival flora. J Periodontol Res 1991; 26:24-32.

12. Palcanis KG, Larjava IK, Wells BR, Suggs KA, Landis JR, Chadwick DE, et al. Elastase as an indicator of periodontal disease progression. J Periodontol 1992; 63:237-42.

13. Gustafsson A, Asman B, Bergström K. Granulocyte elastase in gingival crevicular fluid. J Clin Periodontol 1994; 19:535-40.

14. Armitage GC, Jeffcoat MK, Chadwik DE, Taggart Jr, Numabe $\mathrm{Y}$, Landis JR, et al. Longitudinal evaluation of elastase as a marker for the progression of periodontitis. J Periodontol 1994; 65:120-8.

15. Ohlsson $\mathrm{K}$. Interaction of granulocyte neutral proteases with alpha-1-antitrypsin, alpha-2-macroglobulin and alpha-1-antichymotrypsin. In: Havemann K, Janoff A, editors. Neutral proteases of human polymorphonuclear leukocytes. Baltimore and Munich: Urban and Schwarzenberg 1978:167-77.

16. Robert L, Hornebeck W. Elastin and elastases. (vol I and II) Boca Raton FL: CRC Press, 1989.

17. Tyagi SC, Simon SR. Inhibitors directed to binding domains in neutrophil elastase. Biochemistry 1990; 29:9970-7.

18. Legras S, Diczhazi C, Moczar M. N-oleoyl heparin inhibits the amidolytic activity of plasmin and urokinase. Int J Biol Macromol 1992; 14:97-9.

19. Ashe BM, Zimmerman M. Specific inhibition of human granulocyte elastase by cis-unsaturated fatty acids and activation by the corresponding alcohols. Biochem Biophys Res Commun 1977; 75:194-9.

20. Baici A, Diczhazi C, Neszmelyi A, Moczar E, Hornebeck W. Inhibition of the human leucocyte endopeptidases elastase and cathepsin $\mathrm{G}$ and of porcine pancreatic elastase by $\mathrm{N}$-oleoyl derivatives of heparin. Biochem Pharmacol 1993; 46:1545-9.
21. Walsh RL, Dillon TJ, Scicchitano R, McLennan G. Heparin and heparan sulfate are inhibitors of human leucocyte elastase. Clin Sci 1991; 81:341-6.

22. Bizot-Foulon V, Godeau G, Guessous F, Lati E, Rousset G, Roch-Arveiller M, et al. Inhibition of human neutrophil elastase by wheat ceramides. Int J Cosmetic Sci 1995; 17:255-64.

23. Guessous F, Huynh C, N'Guyen H, Godeau G, Giroud IP, Meyer J, et al. An animal model for the assessment of gingival lesions. J Pharmacol Meth 1994; 32:161-7.

24. Ciret P, Liance MC, Henninger JM, Cazalet C, Guest M. Evaluation d'un laser immunonéphélomètre. Application au dosage des protéines sériques. Pharm Biol 1978; 113:37-40.

25. Valazza A, Matter J, Ogilvie A, Cimasoni G. Fluide gingival, inflammation gingivale, profondeur des poches et perte osseuse. Rev Mens Suisse Odonto-Stomatol 1972; 82:824-32.

26. Baici A. The specific velocity plot. A graphical method for determining inhibition parameters for both linear and hyperbolic enzyme inhibitors. Eur J Biochem 1981; 119:9-14.

27. Bonnaure-Mallet $M$. Comportement des formations élastiques gingivales dans les maladies parodontales. Pathol Biol 1991; $1: 42-6$.

28. Lafuma C, Frisdal E, Robert L, Moczar E, Lefrancier P, Hornebeck W. Lipopeptides as bifunctional inhibitors; prevention of elastase-induced emphysema in mice by intratracheal pretreatment with oleoyl-alanyl-alanyl-prolyl-valine. Second Forum on Peptides, Paris, May 1989. Ed A Aubry, M Marraud, B Vitoux. Colloque INSERM 1989; 174:321-4.

29. Kerneur C, Hornebeck W, Robert L, Moczar E. Inhibition of human leucocyte elastase by fatty acyl-benzisothiasolinone, 1,1-dioxide conjugates (fatty acyl-saccharins). Pharmacology 1993; 9:1889-5.

30. Adeyemi EO, Chadwick VS, Hodgson HJF. The effect of some anti-inflammatory agents on elastase release from neutrophils in vitro. J Pharm Pharmacol 1990; 42:487-90.

31. Knight WB, Maycock AL, Green BG, Ashe BM, Gale P, Weston $\mathrm{H}$, et al. Mechanism of inhibition of human leukocyte elastase by two cephalosporin derivatives. J Am Chem Soc 1992; 31(21):4980-6.

32. Dobrowsky RT, Hannun YA. Ceramide stimulates a cytosolic protein phosphatase [communication]. J Biol Chem 1992; 267:5048-51.

33. Rao NV, Kennedy TP, Rao G, Hoidal JR, Ky N. Sulfated polysaccharides prevent human leukocyte elastase-induced acute lung injury and emphysema in hamsters. Am Rev Respir Dis 1990; 142:407-12.

34. Lafuma C, Frisdal E, Harf A, Robert L, Hornebeck W. Prevention of leukocyte elastase-induced emphysema in mice by heparin fragments. Eur Respir J 1991; 4:1004-9.

35. Moczar E, Hornebeck W. A lipophilic heparin derivative protects elastin degradation by leucocyte elastase. Int $\mathbf{J}$ Biol Macromol 1991; 13:261-2.

36. Regnault C, Roch-Arveiller M, Tissot M, Sarfati G, Giroud JP, Postaire E, et al. Effect of encapsulation on the anti-inflammatory properties of superoxide dismutase after oral administration. Clin Chim Acta 1995; 240:117-27.

37. Regnault C, Fessi H, Benoist C, Roch-Arveiller M, Postaire E, Hazebroucq G. Preparation of superoxide dismutase entrapped in ceramide-containing liposomes for oral administration. Int J Pharmacol 1996; 132:263-6.

Received May 20/July 25, 1997

Corresponding author: Dr. M. Roch-Arveiller, Laboratoire de Pharmacologie, Hôpital Cochin, Pavillon Gustave Roussy, 27 rue du Faubourg Saint-Jacques, 75679 Paris cedex 14, France 
